\title{
Edward L. Rubin, Soul, Self and Society. The New Morality and the Modern State
}

\author{
Carel Smith
}

Edward L. Rubin, Soul, Self and Society. The New Morality and the Modern State (Oxford: Oxford University Press, 2015), $504 p$.

Is it immoral to kill a friend who has seriously insulted her? To have sexual intercourse with his lawful wife against her will? To ram a ship that illegally hunts whales? According to Edward L. Rubin in his book Soul, Self, and Society, the correct answer to these questions depends on the moral order of which one is a part. He distinguishes three moral orders that have developed successively in the Western world since the fall of the Western Roman Empire: the morality of honor, the morality of higher purposes, and the morality of self-fulfillment. Morality, according to Rubin, is not a given, immutable and autonomous phenomenon: it is something that takes shape under the influence of the architecture of the public administration of an era. The relation between both is complex: morality and governance stand together in a relationship of co-causality, in that governance is as much the result of the ruling moral code as the moral code is shaped by the form of governance. Soul, Self, and Society elaborates this thesis from the fall of the Western Roman Empire to the present. During this long period, a multitude of forms of government existed, but Rubin determinedly reduces these to three basic forms: feudal order, royal government, and administrative government.

The motive for this study is the culture wars between conservatives and progressives that have held American society in their grip for decades. According to Rubin, this is the result of the transition from the morality of higher purposes to that of the morality of self-fulfillment. Such a transition has already taken place once before, at the intersection of the early to the late Middle Ages, when the morality of higher purposes replaced the morality of honor - a process of centuries. The first part of Soul, Self, and Society discusses the transitions of the three moral systems in connection to the changes of governance. In the second part of his book, he focuses on the interaction between the administrative state of the 19th and 20th century and the connected transition from the morality of higher purposes to the morality of self-fulfillment.

Soul, Self, and Society is an ambitious book. It not only seeks to substantiate the claim that the moral codes of the Western world of the past 1500 years can be reduced to three moral orders, but also that each moral order is intimately connected with a particular form of governance. Although Rubin explicitly states (p. 15) that his book is confined to these two purposes - description and explanation - the actual purpose of the book seems to me a normative one, as it seeks to demonstrate that moral systems become anachronistic, and therefore immoral, once 
they no longer fit the new type of governance. The blood feuds of the early Middle Ages are the correlate of a morality based on values such as loyalty and honor, which are indispensable in a society without central authority. Blood feuds become a threat, however, in a centralized society, where security and justice no longer depend on the strength, courage and ruthlessness of local leaders, but on the impersonal organizations of the state: police, courts, army. According to the same logic, the morality of higher purposes is doomed to disappear as well. The loud resistance of traditionalists and conservatives against the beacons of what Rubin calls High Modernity (gay marriage, equality between man and woman, sexuality as a form of self-realization) is actually already an anachronism. Their resistance is the convulsions of a worldview that belongs to the pyramidal society of royal absolutism, where everything and everyone has its permanent place.

The rise of the administrative state at the beginning of the 19th century emphasizes a different value: that of the self-realization of its citizens. Democratization (American and French revolution), utilitarianism (Bentham), reform of criminal law (Beccaria), psychoanalysis (Freud), Rubin sees the signs of the new order appearing everywhere. Thanks to the dynamic process of co-causality between morality and governance, the new morality of self-fulfillment is taking shape. In the light of the new morality, supported by a public administration that aims to facilitate the infinite possibilities of self-realization, sticking to the morality of higher purposes is not only anachronistic, but also immoral: it demands that people adhere to prescribed roles regardless of nature, expertise and ambition, without this being required any longer for the functioning of society. This is the key message from the second part of Rubin's book.

Soul, Self, and Society offers a provocative account of how the modern administrative state has transformed our moral codes. Its intellectual scope is breathtaking: the references cover a quarter of the book, ranging from the Church Fathers, medieval chronicles and songs to the Encyclopedists of the Enlightenment and the novels of High Modernity. Yet, despite its impressive erudition, I am not entirely convinced by the book for two connected reasons. First, from Rubin's principle of co-causality, it follows that the administrative state is just as much the result of the morality of self-fulfillment as it has caused this morality. This makes it problematic to declare the morality of higher purposes obsolete with an appeal to the rise of the administrative state. One can assert the reverse as well, as the defenders of traditional values actually do. They consider the emergence of the administrative state not as the 'proof' that the morality of higher purposes has had its longest time. Rather, they consider it the result and product of a decadent morality - and thus as something that must be contested and abolished. The fact that all signposts in Rubin's book point in the other direction exhibits, in my opinion, the actual purpose of the book: demonstrating that the morality of higher purposes is outdated. There is nothing wrong with that, of course, but the danger of hineininterpretieren is then lurking.

In my opinion, that danger has indeed been realized - that is my second doubt with the book. Rubin's immense scholarly knowledge, of which the book testifies, 
is beyond dispute. Erudition, however, can also be an obstacle that keeps us from leaving the beaten roads of tradition. Despite the originality of Rubin's claims, the narrative of progress proves to be so strong a narrative that it serves, in Rubin's study, as the blue print of history. It leads towards what is called a 'Whig interpretation of history,' in which the course of history necessarily leads from barbarism and ignorance to the enlightened ideals of one's own time. Rubin, of course, never used those words. Instead, he claims that one must value the moral systems in their societal contexts. It is nevertheless hard not to glimpse this narrative of progress between the lines, especially when he compares the morality of High Modernity with the pre-modern moral systems. Two quotes may illustrate my point: 'Both previous moralities urged a person to pay assiduous attention to the view of others (...) The morality of self-fulfillment insists that people define their own positions and their own pathways through life' (p. 163). And one page further, he states that the pre-modern literary heroes, like Roland or El Cid, are defenders of the existing order, even if they question its value, such as Achilles and Hamlet, whereas '[m] odern heroes think for themselves.' That is the language of progress. It implies that 'we' (the progressives) are free, whereas 'they' (our ancestors, the conservatives) are subject to a given order, and, by consequence, not free. This narrative turns a blind eye to the similarities between the different codes: although the moral codes changed, we are still bound by moral imperatives, and these are as binding to us as our ancestors were bound to the 'older' imperatives. Similarly, how the morality of human dignity, from which sprung the fundamental human rights, should be qualified seems a matter of perspective. In exercising these rights, one can rightly speak of a morality of self-fulfillment. However, by regarding human dignity as the goal and justification of the political order, one can speak as well of a morality of higher purposes, and especially so since the idea that man possesses 'inalienable' rights has its source in natural law theory.

The narrative of progress, in short, is a normative perspective on history and morality that both reveals and conceals. It means that Rubin has taken side in the culture wars. The tenor of the book is, of course, convincing for the proponents of the morality of higher purposes. From a critical perspective, however, one would have wished that Rubin, with his erudition and imagination, would have been less partisan and had written a study that the culture wars need most: a perspective from the outside with refreshing and sometimes unsettling observations and insights, rather than statements that primarily confirm our progressive prejudices. 